\title{
Motorbike as a Fiduciary Object at Financing Institution of Subsidiary PT. Adira of Denpasar
}

\author{
Anak Agung Ayu Sri Wulan Jayanti ${ }^{1}$ and Luh Putu Sudini ${ }^{2}$ \\ \{gungwulan83@yahoo.com¹ and sudini_putu@yahoo.com² \\ Universitas Warmadewa, Denpasar, Bali - Indonesia
}

\begin{abstract}
This study explores the regulation of fiduciary institutions in financing companies and the implementation of the imposition of motorbike as fiduciary at the financing company in Denpasar city. This study applies a qualitative research design. Results show that Fiduciary Institution in the financing company is strictly regulated in the Laws number 42 Year 1999 on Fiduciary; it is the transfer of property rights to the goods as a guarantee on the basis of trust, while the object itself remains in the hands of the owner. The implementation of imposition of motorbike as a fiduciary at a financing company in PT. Adira Denpasar is an absolute requirement for the purpose of legal certainty that is expressly regulated in the credit agreement. This is because fiduciary security is very important for financing companies to counter the risks that may arise in the future as a result of lending by the company.
\end{abstract}

Keywords: Fiduciary object; financing company; motorbikes

\section{Introduction}

In the development of the world of companies and businesses, there are often found several kinds of service companies providing the source of capital [1]. In general the sources of capitals in Indonesia can be served by the Monetary Agencies and Finance Agencies [2]. With that condition the society will have more choices. With more choices the society will need more money and then the economic rounds very high and very fast itself. When this happens the economic growing level governed by the government will be achieved, and the result later on is that the society's prosperity level will increase as well [3]. In general the Finance Agencies can be classified into three large groups, i.e Banks' Finance Agencies, NonBanks' Monetary Agencies and Finance Agencies [4].

The Finance Agencies are divided into six classifications, i.e: (1) Leasing (2)Venture Capital (3) Securities Trade (4) Factoring (5) Credit card and (6) Consumes finance [5].

Due to the Finance Companies there is certainly distribute money loans, such as credits to buy a certain thing needed by someone, for example a motorbike, so, it means the finance company distributes credits to consumers. These kinds of credits are certainly very crucial, i.e the credits can be in loss if the debtor defaults [6]. In order to anticipate it, the item bought by the company, the finance is left to the consumers to use, then binded as a collateral by using the Fiduciary Collateral Agreement as managed in the Statutes Number 42 Year 1999 about Fiduciary Collateral (which is then called as Fiduciary Statutes).

The usage of Fiduciary Collateral Agencies in the Consumers' Finance Agencies, at a glance, seems to give more permanent collateral in protecting investment related to the preference rights from the Fiduciary Collateral towards the Consumers' Financial Agencies 
related [7]. However, the truth of this opinion has not been researched in detail, because the formal aspects in Fiduciary Collateral have mechanism and procedure in order to be able to give law protection for the Consumers' Finance Agencies themselves, for example the rules about the Fiduciary Enrollment procedures.

According to the Chapter 11 Fiduciary Statutes requires the items burdened with the collateral fiduciary registered in the Fiduciary Registration Office functions to give Law Certainty.

Based on the above understandings, the reality available in practice, there are a lot of deviations in terms of Fiduciary Collateral burdens, they can be seen after the signing of the consumers' agreement and the agreement of fiduciary between the creditor and the debtor has not been registered, especially the consumers' vehicle agreement, directly the ones handed over to the creditors are the motorbikes and the Vehicles Registration (STNK) only, meanwhile the proof of the ownership, i.e: the Ownership Motor Proprietary Books (BPKB) have been kept by the creditors as the payment guarantees on the debts if in the future the debtors default or negligence [8].

A lot of happenings that before the whole credits are paid all by the default debtors, the monthly credits are not paid anymore and the vehicles have been handed over to the third parties without the notice and the permission from the fiduciary receivers (creditors).

The problems above are very at risk juridically, mainly towards the bought items/the ones funded by the Institutions of Consumers' Finance which are absolutely becoming the consumers' belongings, so it is common by the institutions of finance embedded Collateral Fiduciary, besides in order to avoid any loss that might be beared by the institutions of finance, so in the agreement (due to the items have been mastered by the consumers) the consumers are prohibited to divert their properties to the other parties either by buying and selling or pledge before the financing agreement expires.

Procedurally, in order to understand the rights of preference born from the Statutes of Fiduciary cannot be released from the law mechanism related to the Statutes themselves, they are: in coincidence to the registration mechanism of collateral fiduciary based on the Government Regulation of the Republic of Indonesia Number 86 Year 2000 about the Registration Rules of Collateral Fiduciary and the making Costs of Collateral Fiduciary Acte.

In regard to the institution of this Collateral Fiduciary there are really a lot of problems coming up because the items that are to become the objects of collateral fiduciary often difficult to be categorized as what kind of items based on the Statutes of Civil Law which are more familiar with important items division, i.e. moving items and non-moving items. Are the agreement objects of collateral fiduciary be able to be categorized into one of the divisions of moving items or categorized into non-moving items as managed by the Civil Law. In other words, for these times the items which are to become the agreement objects of collateral fiduciary can be categorized specifically according to the development of nowadays. If it is right the items which are to become the objects of the fiduciary agreement in fact by the Fiduciary Statutes stated to remain available on the debtors' hands, certainly this case has its reasons. These are half of some problems raising in the Fiduciary Statutes which are a lot coming up in practice.

\section{Discussion}

\subsection{Institution Management of Collateral Fiduciary in Financing Company}


The importance of institution guarantee in life nowadays such as business activities is in its efforts in the needs of credit facilities. And, in order to get them it is required the availability of guarantee for the sake of capital safety and law certainty of the capital giver [4]. In this case, the Statutes Number 42 Year 1999 about the rights of responsibility and the explanations are also determining firmly.

This institution fiduciary in the beginning raises based on the societies' needs on credits with the guarantee of moving-items, meanwhile it still needs those moving-items in order to be able to be used for company needs or daily works. If the pledge guarantee is taken in searching for credits guarantee will be in contrast to requirement of inbeitstelling, i.e as one of the requirements in pledge that is the items must be available in the power of attorney of the pledge holders according to the Chapter 1152 Civil Law, as in the samples of the the above foreword. The requirements of inbeitstelling justifying the items guarantee are in the mastery of creditors in which their developments facing difficulties due to the societies' needs require items guarantee to remain in the mastery of the guarantee givers. Therefore, in order to facilitate the societies' needs, the Court Justice issue regulations to become juryprudency that is the items guarantee remains in the mastery of the guarantee givers and finally the Statutes Number 42 Year 1999 about Collateral Fiduciary are regulated.

Chapter 1 Number 2 of the Act of Fiduciary Number 42 Year 1999 stipulates:

"Collateral Fiduciary is the rights guarantee on moving items both in formula and nonformula and non-moving items especially buildings which are burdened rights of responsibillity as intended in the Statutes Number 4 Year 1996 about rights of responsibility remaining in the mastery of Fiduciary Givers as a collateral for certain debts payments giving positions specially referred to the fiduciary receivers towards other creditors."

Based on the regulations, fiduciaire eigendoms overdracht is the ownership rights on items as a guarantee of which handing over based on trust, meanwhile the items themselves are still on the debtors' hands so they remain to be able to be used for companies, etc [9]. If seen from the procedures of implementations the relationship happens between the creditors party and the debtors party can be qualified there have been law relationship between creditors side and debtors side which are in each embedding in theirselves the right and compulsory on achievement [10].

The debtors' compulsory for achievement must be implemented, if the debtors do not implement it, so the creditors that have been protected can put on some sanctions to the debtors both as a change for loss and money forcement, execution in order that the debtors fulfil the achievement promised [8].

Therefore if seen from the law relationship in this fiduciary, so there will be the things, i.e: (1) Law relationship/law action (2) Subjects consists of creditors side and debtors side and (3) Objects as wealth.

If seen from the happening process of ownership rights as guarantee with fiduciary throughout several phase:

a. Agreement availability that is consensual/obligatoire. It means that the fiduciary giver party and the fiduciary receiver party hold an agreement whereas determined by the debtors who have borrowed some money to the creditors with a promise that will hand over their property as fiduciary guarantee.

b. Items agreement availability, it means that between both parties the fiduciary giver and receiver, there has happened items guarantee handing over like constitutum possessorium meaning that property rights handing over as a guarantee from debtors to creditors whereas the item as a guarantee handed over remains on the power of attorney in real from the debtors. 
c. The availability of usage borrow agreement, it means that between both parties the fiduciary givers and the fiduciary receivers have held an agreement that the fiduciary owners give the borrow usage of their ownership rights on property that have been on their power of attorney to the fiduciary receivers [11].

The ownership rights of property handing over fiduciarily in practice has been developing as such a very up-to-date thing nowadays, so not only having company inventory of commercial items, machines, vehicles, etc, but also non-moving items, for example: houses, shops, buildings over someone else's lands with rights of leasing or rights of rental that can be fiduciarized [12].

As having been explained before that this institution is coming up because of daily practice or needs and ritual of societies who require the availability of practical institutional guarantier. This fiduciary institution has been registered in the Statutes both in Indonesia and overseas. These collateral fiduciary institutions have been known before since the Roman era with the name of "Fiducia Cumcreditore" and in the Netherlands recognized by Hoge Raad [13]. At the beginning in his arrest dated 25 January 1929 (Bierbrowerij Arrest), meanwhile in Indonesia based on Arrest Hoggerchtshof dated 18 August 1993 (BPM Chynett) is at once as the first jurisprudency as a collateral institution.

This fiduciary institution in law practice after Independence Day, we can find out its law certainty in Surabaya Court Justice Judgement dated 2 March 1950 No. 158/1950 that has cancelled Semarang Court Justice Judgement dated 21 April 1950 No. 165/1949/L CIV underlining that ownership handing over based on trust is only permitted to moving-items due to its handing over is only permitted as a chance for the parties having inquiries to hold another agreement rather than pledge agreement managed in Title XX Book II Civil Law, but the other agreement is however obliged to including moving-items as Title XX concerning about.

Based on the consideration from the intended decision, so it will be real that the Court eventhough gives salute to Fiduciary Institution, meanwhile, based on the point of view from the Netherlands' Judge Judgement merely looking at fiduciary as an expansion from Pand Institution, not as a free guarantee. Meanwhile, jurisprudency development in Indonesia then based on the judgement from the Supreme Court of the Republic of Indonesia dated 1 September 1971 (as valid in Indonesia Jurisprudency on the Eleventh Publicity Year 1972), for example about the cases between Lo Ding Siang vs Indonesia Bank, stating that the ownership hand over agreement as fiduciary assignment is only valid as long as in regard to moving-items. Supreme Court states that it is invalid for ownership hand over as an assignment on Buildings of Office PT. Bank Pengayoman at Jalan Kepondang No. 29/31 Semarang with their inventory.

Supreme Court in their judgement do not explain what their consideration is, why it is invalid for ownership agreement as an assignment on buildings of the offices and their inventory, whether the buildings are on the lands of own right, leasing right or building use right of which all are the rights that can be burdened hypotic/credietverband, so it is in accordance if fiduciary agreement considered not valid.

In relation to the above matter, further developments of economic grow and needs that can include financial needs of societies need to be balanced with the expansion of assignment institutions which are already available.

The assignment institutions need to be included in the Statutes, exclusively the availability of facts in Indonesia, i.e:

a. Small companies, shops, small shops, restaurants, etc need money for expansion their businesses with the guarantee of their sold items. 
b. Employees and households need money for their household needs with the guarantee of their stationary household.

c. Rice companies and palm companies need money for their business expansion with the guarantee of their prawns and fabrics or factories.

d. Agricultural businesses need money for increasing the results of agriculture with the guarantee of agricultural appliances [9].

The societies' needs development, economic development and financial development through credits in Indonesia societies nowadays need the forms of assignment institutions besides the forms of guarantee as managed in the Statutes such as hypotic assignment institution, credietverband and pledge institution. The societies' needs require the forms of guarantee whereas people can get credit loan appeal with the guarantee of moving-items, meanwhile, people still remain to be able to use it for daily needs and their business needs. Credit appeal assignment on moving-items holds more and more important roles in various modern countries, including Indonesia. Such credit assignment cannot be inclusive just in pledge regulations that are not possible for the guarantee only on the party who puts on the pledge due to in contrast with the requirement of invezitztelling required in the pledge based on Chapter 1162 Article 3 Civil Law, meanwhile the Arrest has a different opinion in relation with the societies' needs development.

In a matter of this credit facilities sharing in practice of collateral, it is even more dominant or to be more proposed specially, so collateral is really more important than merely a guarantee in term of trust on debtors' capability in order their debts to be all-paid. That kind of matter is really basic due to the guarantee is just an abstract thing whereas its judgement is very subjective, different from the clear collateral so by the objectivity and economically as well if there happens a default from the debtors or problematic credit availability then afterwards the bank quickly is able to converse to a number of more liquid money. In order to increase trust on character and capability of debtors, financial companies always ask a guarantee of credit sharing from other parties such as private assignment, guarantee from the parties of financial companies or assignment from central companies.

Assignment is something shared by the debtors to creditors in order to raise trust that the debtors will fulfil the obligatory that can be valued for money raised from one binding [14].

Credits shared by the financial companies is based on trust, therefore the credit sharing is a trust sharing to clients. As a result, the credit sharing may only continue the societies' saving to their clients in term of credit, if they are really certain that the debtors will return the loans received according to the period of time and requirements agreed by both parties. It determines necessary to pay attention to the capability and desire factors.

The essential credit sharing in term of trust rising up due to the fulfilment of all conditions and requirements to get company financial credit by debtors, they are: the clarification of credit aims, the availability of assignment or guarantee items, etc. So it is found that the meaning of trust in credit sharing, i.e the trust from the bank as creditors that the credit given is really re-accepted in certain period of time according to the agreement.

The trust factor which is as an essential credit sharing in the credit sharing is also including other factors, i.e the factors of time, risk, and achievement.

The factor of time is certain length of time or certain period of time between credit sharing or credit liquidation by the company finance with credit payment by debtors. In fact, the credit payment is undertaken throughout credits of a certain time according to the debtors' capability.

One item which is to become fiduciary object is based on good willingness from the debtors for ensuring the total payment of all debts as mentioned in the basic agreement will be 
well-completed, meanwhile, the creditors are becoming more and more certain to the debtors' good intention, if there are certain items having economic values binded in an agreement known by material guarantees. If the object guarantees are materials but they do not have economic values, these are not material guarantees but individual guarantees. Guarantees must be mastered in term of their law rights legally by the debtors and/or guarantors and then can be accepted by the creditors due to the warranties are considered valuable. So if the debtors and/or the guarantors do not want to lose those material guarantees, so the debtors must pay off their debts. Similarly, the creditors hope that the sale of collateral goods can reasonably settle their receivables while the debtors default [15].

This realization of guarantee is also always like selling collateral goods and taking the result of selling the collateral goods as to becoming the benefits of beneficial parties (the creditors). So the ones guaranteed are always the fulfilment of an obligation that can be valued by money. Therefore, the goods that can be a warranty must be an object or the right that can be valued by money.

Based on the above opinions of university graduates, it can be concluded, they are: the object warranty agreement requirements are objects having economic values and can be handed over. Those requirements are for protecting the interests of creditors while debtors default on pledge so the object as the pay off on the debtors' debts to the creditors. The creditors as the holders of rights on warranty have a huge interest over high fixed-value of objects warranty, primarily while they are going to execute the objects warranty. Due to the greater ther results of objects warranty selling, the greater also the due possibilities of charging rights paid from the objects warranty selling.

Based on the descriptions explained above, it is clearly seen the important meaning of warranties in credits sharing done by company finance. As they have been explained in the chapters before, they are: all warranty binding agreements are accessoir. It means that the existence of warranty binding agreements depends on its basic agreement, that is, credits agreement [11]. Salim argues that: "Basic agreement is an agreement to get credits facility from banking institutions or non-banking finance institutions [16]."

Based on the above explanations, the theoretical basis used as knife analysis is the Law Certainty Theory from Soedikno Mertokusumo, by the availability of fiduciary guarantee binding for both creditors and debtors will it be able to get what being expected are in certain condition. For creditors, by the availability of fiduciary warranty binding, if the debtors do default, so the rights of creditors for taking back their receivables can be fulfilled by selling objects warranty of which are fiduciary objects warranty. Meanwhile for the debtors are the rights to be able to use the objects warranty to be fulfilled by the availability of fiduciary warranty, eventhough the objects used as debts warranty.

\subsection{The Implementation of Motorbike as Fiduciary Object at Financing Company of Subsidiary PT. Adira of Denpasar}

It has been explained in the discussion before, about the position of warranty up to the importance of warranty in credits sharing by company finance. In order the warranty application in credits sharing is well-run, so it needs law regulations about firm warranty. Whereas they can give safety for the parties involved in the credits agreement, especially for the Company Finance Party as Creditors and Customers Party as Debtors.

When examined deeper, there are law problems, especially about law certainty in regard to the warranty which has not been summarized in a strict provision. It can be seen from the Terms of the Article 8 of Law Number 10 Year 1998 on Banking: 
In sharing credits, public banks are obliged to have confidence on the debtors' willingness and capability to pay off their debts in accordance with the agreement.

Further about the Article 8 Law Number 10 Year 1998 about the Changes on the Law Number 7 Year 1992 regarding the Banking confirms that:

In giving credits or finance based on sharia principles, commercial banks are required to have confidence based on in-depth analysis on debtors' customers' good intention and capability and then willingness to pay off their debts or return the intended-finance in accordance with the agreement.

The regulations regarding warranty in sharing credits by company finance and banking institutions as mentioned above, they can raise up uncertainty in implementing sharing credits. The uncertainty is due to the unclear regulations in setting about the obligatory guarantee availability in every credits sharing by company. Whereas the guarantee is actually a very important thing for the company finance party to ward off the risks that may happen in the future as the effect on sharing credits by the company finance.

Based on the results of interview dated 9 March 2018, in practice of PT. Adira Denpasar, i.e: the credits sharing by the company party to debtors with guarantee, besides with the availability of trust from the Parties of Creditors and Debtors, with the availability of objects guarantee like motorbike are absolute requirements obliged to be available for the law certainty and their functions for both parties the creditors and the debtors and the requirements of this guarantee have been set up clearly in the credits agreement [17].

In the field practice as Mr. Arif has seen as Credits Analyst of PT. Adira Denpasar, according to him the societies' members mobility level in their efforts to fulfil their needs, also their smoothness facility that must be cheap becoming vehicles as suitable choices to achieve them all. According to him the vehicles requests from time to time continue increasing. The societies who are less able to buy them asking help to Adira for buying them [18].

The company finance as the societies' public funding institution throughout credits sharing needs a guarantee as an assurance that the credits given will return in accordance to the agreement. The guarantee needed by the company must have economic values as the requirement. It is no wonder if the company prefers kinds of guarantee which are materialistic for credits sharing requirement. The guarantee is said to be a form of debts binding agreement that is an additional agreement as having been explained above.

In practice, this matter of credits facility sharing, the collateral according to the writer, it is felt very dominant or prioritized, so the collateral is really more important than just only the guarantee as the assurance on the debtors' capability to pay off their debts. It is really very basic due to the guarantee is an abstract thing of which its assessment is very objective and economically if default happens to the debtors or there is a problematic credit so the banks immediately can converse it to a number of money in cash.

According to the above descriptions that the collateral in practice is more prioritized in this credits sharing, so there is no excess if the company finance considering necessary in increasing the trust and assurance on the customers' character and capability, the company always ask for the credits guarantee sharing from other parties like personal guarantee or personal warranty from the other company or guarantee from the parent company. The individual guarantee or personal guarantee is someone's guarantee of third party undertaking to guarantee the debtors' obligations fulfilment. This guarantee can be done without the debtors' acknowledgement. According to Soebekti, it is due to the creditors' demands to one guarantor who is not provided with a privilege or a privileged position compared to the other 
creditors' demands, so this personal guarantee is not much practiced in the world of finance institution.

The procedure that is usually done in the guarantee loading throughout fiduciary, it is done in the form of Guarantee Submission Agreement and Authorization based on the credits agreement that has been agreed. It is different from the hypotic i.e: the goods remain on the Party od Debtors for the sake the smooth running of the business.

For the the world of finance service, the credits without guarantee is a kind of credits involving big risks, therefore, there are no banks in Indonesia issuing this kind of credits, and so do the PT. Adira Denpasar as an institution of funds raiser from and for the societies that will apply for the principle of carefulness of the company in every credit sharing to customers (debtors). With the background of the princple there are many company finance sharing credits to customers (debtors) by asking for guarantee or known as credits with guarantee as one of the ways minimalizing the risks of loss beared due to the customers (debtors) are unable to pay off their credits in accordance to the agreement.

As stated by Moch Isnaeni, "The colorful pattern of economic growth which is much characterized by the activity of the appearance of a credit agreement giving an illustration that the funds supplied by the company finance must be saved as tight as possible, remembering the funds are from the societies' pocket in large [8].

From the explanations, the most important thing is that the company finance in the activities of giving the credits finance must be based on a guarantee, giving an assurance to the banks on the debtors' willingness to pay off the credits in accordance to the agreement. It is implemented at PT. Adira Denpasar.

Based on the interview results with the Manager of PT. Adira Denpasar Branch saying that PT. Adira in their implementation in the societies will co-operate with the Notary when they are making the Fiduciary Guarantee Acte. Because the Fiduciary Guarantee Acte will be saved in the Public Notary. PT. Adira will have accepted the Fiduciary Guarantee Acte completely from the Public Notary and the Party of PT. Adira are just to pay the Public Notary in relation to the making costs of the Fiduciary Guarantee Acte. If default happens, it is used as the basic execution accompanied by the Police. The fiduciary guarantee execution depends upon the Regulation from valid the Financial Service Authority (OJK). The ownership right of PT. Adira and the consumers' usage right of PT. Adira are prohibited to execute arrogantly. The valid Regulation of the Financial Service Authority (OJK) at present may not do the execution individually; they must co-operate with PT. Devkolector. If there is a problem, PT. Adira will remain be responsible to it [17].

Based on the above explanations, the theoretical basis used as the knife analysis is the trust theory from Mokhamad Arwani that is by the availability of integrity/good intention, by the availability of high intention and competence from the Party of Debtors so they can arise up the Creditors' Trust to give credits, nevertheless it remains as well for the sake of the Creditors' safety in order to ask for the guarantee like a motorbike as the Fiduciary Guarantee Object.

Besides, it can be related to the theory of expediency being developed by Jeremy Bentham saying that the Creditors Party can implement the material selling to be the fiduciary Guarantee Object, the benefits for the creditors if the debtors default so the material used by the creditors is the one exposed in the Fiduciary, meanwhile the debtors' other wealth remains protected. If the debtors can implement their obligation rightly so they can take back the material that is to be the Fiduciary Guarantee Object. 


\section{Conclusion}

By making the Fiduciary Guarantee Binding Acte notariily, will it be able to give law certainty, both to debtors and creditors. So they can get a certainty about what they expect in a certain condition.

Additionlly, by implementing the Fiduciary Guarantee, will it turn out the creditors' trust to the debtors as an absolute thing. Nevertheless, it needs an additional guarantee like a motorbike but if the motorbike is mastered by the creditors, so the debtors cannot use the motorbike. Therefore, the Fiduciary Guarantee is a good solution that is beneficial both for the debtors and the creditors. Due to on one side the creditors get a guarantee upon their receivables, on the other side the debtors can use a material like a motorbike to be used by them.

Acknowledgements. The authors express the greatest gratitude to the organizing committee of the International Conference on Social Sciences (ICOSS) of Universitas Warmadewa for the great contribution that has been granted to the launching of this scientific script at EAI Publisher. Hopefully the ideas found in the paper can be additional to the theoretical and practical knowledge for many parties.

\section{References}

[1] Persakis, A and Iatridis, G, A.: The joint effect of investor protection, IFRS and earnings quality on cost of capital: An international study, J. Int. Financ. Mark. Institutions Money, vol. 46. pp. $1-29$ (2017)

[2] Middleton, D, J.: The legal and regulatory response to solicitors involved in serious fraud: Is regulatory action more effective than criminal prosecution?, Br. J. Criminol., vol. 45 (6). pp. 810-836 (2005)

[3] Devi, S.: Pengaruh Enterprise Risk Management Disclosures dan Intelectual Capital Disclosure Pada Nilai Perusahaan, J. Akunt. dan Keuang. Indones., vol. 14 (1). pp. 20-45 (2017)

[4] Muhammad, A.: and Murniati, R.: Segi Hukum Lembaga Keuangan dan Pembiyaan. Bandung: Citra Aditya Bakti (2000)

[5] Berger, A, N and Bouwman, C, H, S.: How does capital affect bank performance during financial crises $\alpha$, J. financ. econ., vol. 109 (1). pp. 146-176 (2013)

[6] Supariyani, N.: Implementasi Ketentuan Restrukturisasi Kredit terhadap Debitur Wanprestasi pada Kredit Perbankan, J. Magister Huk. Udayana, vol. 5 (281-291) p. 11 (2016)

[7] Amihud, Y, et al.: Distressed Debt Restructuring in the Presence of Credit Default Swaps What Determines A Distressed Firm's Choice between in-and out-of-court debt renegotiation? A large body of theoretical and empirical research, vol. 48 (1) (2016)

[8] Isanaeni, M.: Noktah Ambigu Norma Lembaga jaminan Fidusia. Surabaya, Indonesia: PT Revka Petra Media (2017)

[9] Sofwan, S, S, M.: Hukum Perdata Hak Jaminan Atas Tanah. Yogyakarta: Liberty (2001)

[10] Harahap, Y.: Segi-segi Hukum Perjanjian. Bandung: Alumni (1982)

[11] Badrulzaman, M, D.: Bab-bab Tentang Credietverband, Gadai dan fiducia. Bandung: Alumni (2007)

[12] Pontell, H, N, Calavita, K and Tillman, R.: Corporate crime and criminal justice system capacity: Government response to financial institution fraud, Justice Q. vol. 11 (3) pp. 383-410 (1994)

[13] Ott. S and Schubert, M.: It's the Ad text, stupid: cryptic answers won't establish legal certainty for online advertisers, J. Intellect. Prop. Law Pract. Vol. 6 (1). pp. 25-33 (2011) 
[14] Hadisaputro, H.: Pokok-pokok Hukum Perikatan dan Hukum Jaminan. Yogyakarta: Liberty (1984)

[15] Sofwan, S, S, M.: Himpunan Karya Tentang Hukum Jaminan. Yogyakarta: Liberty (2002)

[16] Salim, H, H, S.: Perkembangan Hukum Jaminan di Indonesia. Jakarta (2004)

[17] Interview with Mr. Anugrah, as Branch Manager of PT. Adira Denpasar, on Friday March 9 (2018)

[18] Interview with Mr. Arif, as Credit Branch Analyst at PT. Adira Denpasar, on Friday March 9 (2018) 